Arch. Tierz., Dummerstorf 50 (2007) 1, 07-24

Institute for Animal Breeding and Genetics, University of Veterinary Medicine Hannover, Germany

DOROTHEE STÜBS and OTTMAR DISTL

\title{
Mapping the horse genome and its impact on equine genomics for identification of genes for monogenic and complex traits - a review
}

\begin{abstract}
Since the beginning of investigation in the horse genome in the early nineties, there has been a great progress, especially during the last five years. At the beginning the exploration of monogenic hereditary diseases was one of the main aims, and the causal mutations of several diseases in the horse have been unravelled. The inheritance of coat colours has been explored very detailed, and there exist gene tests for different coat colours. Information about coat colours and inherited diseases is very important for the breeders and helps avoiding the appearance of lethal genetic factors or undesirable diseases. The most important achievements of horse genome analysis were well-developed linkage, radiation hybrid and cytogenetic genome maps including more than 2950 loci. These maps support comparative analysis of equine hereditary diseases. The present known gene mutations for five diseases in horses have human homologs. Studies on multifactorial diseases such as osteochondrosis and navicular bone disease and on fertility and temperament are underway. At the moment, the whole equine genome is sequenced as it has been done for the human genome and also for other animal genomes. Horse breeding will greatly benefit from identification of QTL for multifactorial traits and gene mutations for congenital anomalies, diseases and performance traits.
\end{abstract}

Key Words: horse, genome, equine maps, coat colours, inherited diseases

\section{Zusammenfassung}

Titel der Arbeit: Kartierung des Pferdegenoms und funktionelle Genomanalyse zur Identifizierung monogenischer und komplexer Merkmale - ein Überblick

Seit den ersten Arbeiten zur Aufklärung von Genen beim Pferd in den 90er Jahren wurden große Fortschritte in der Genomanalyse beim Pferd gemacht. Für fünf monogen vererbte Krankheiten konnten die verantwortlichen Genmutationen aufgeklärt werden. Die Vererbung der Fellfarben auf populationsgenetischer Ebene ist beim Pferd weitgehend geklärt. Für einige Fellfarben, wie die Fuchsfarbe, den Sabino, die Tobiano-Scheckung und den Aufhellungsfaktor (Cream Allel) am Albino Genort, konnten Gentests entwickelt werden. Diese Erkenntnisse über die Farballele sind für die Pferdezucht wichtig, und Gentests für die Erkennung von Anlageträgern helfen, das Auftreten von Erbfehlern und Krankheiten zu vermeiden. Die bisher wichtigsten Fortschritte in der Genomanalyse waren die Entwicklung von genetischen, zytogenetischen und Radiation Hybrid Karten, damit Genorte für monogen und multifaktoriell vererbte Merkmale (QTL) kartiert und anschließend vergleichend analysiert werden konnten. Bisher wurden mehr als 2950 Genloci auf diesen Karten kartiert. Arbeiten zu multifaktoriellen Krankheiten wie Osteochondrose und Podotrochlose sowie zur Fruchtbarkeit sowie zu dem Temperament sind auf dem Weg. Momentan wird das Pferdegenom komplett sequenziert wie dies bereits für den Menschen und andere Haustiere durchgeführt wurde. Die Pferdezucht wird davon für die Identifizierung von QTL und Aufklärung von Genmutationen für angeborene Anomalien, Krankheiten und Leistungsmerkmale erheblich profitieren.

Schlüsselwörter: Pferd, Genom, Genkarten, Fellfarben, erbliche Krankheiten

\section{Introduction}

The first animal genome sequence had been completed already when scientists decoded the sequence of the nematode C. elegans (BETHESDA, 1998). The exploration of mammalian genomes, especially in farm animals, proceeded very fast, and there are several genomes of mammalian animals completed today (FADIEL et al., 
2005). Genome sequencing in other domestic animals, particularly in pets, forged ahead in the last few years, too, because it was a matter of particular interest for breeders. The chicken, dog, and cow genome have been wholly sequenced and work has started in the pig and horse (BETHESDA, 2004).

Having the information on the complete genome sequence is the key on understanding physiological and pathological processes and may revolutionize health research. While scientific investigations had to be confined mainly to the analysis of phenotypic data and pedigrees for familial diseases, today techniques include fluorescence in situ hybridisation (JOHN et al., 1969), somatic cell hybrid panels and radiation hybrid panels (STRACHAN and READ, 1996), comparative mapping (O`BRIEN and GRAVES, 1991), sequence and mutation analysis, gene expression using microarrays or quantitative real time techniques.

New information about mapped genes or markers is shortly posted on one of the databases in the internet and is free available (HU et al., 2001).

The progress in investigation of the horse genome especially in the last ten years is the result of concentrated and well-organized scientific work all over the world: 1995 was the year of the foundation of the International Equine Gene Mapping Workshop. Since 1997 this foundation works together with the Horse Technical committee of the National Research Sponsored Project-8 (NRSP-8) of the United States Department of Agriculture National Animal Genome Research Program (USDA-NAGRP) with the aim to decipher the horse genome as soon as possible.

\section{Organization of the horse genome}

The diploid genome of the domestic horse (Equus caballus) consists of 64 chromosomes, and 13 pairs of the autosomes are biarmed, while the other 18 pairs of the autosomes are acrocentric. The $\mathrm{X}$ chromosome is large and metacentric, the $\mathrm{Y}$ chromosome small and submetacentric. It is remarkable that the equus przewalski genome consists of 66 chromosomes and that 12 pairs of its autosomes are metacentric and 20 pairs are acrocentric. One pair of the horses`acrocentric chromosomes (ECA5) contains two of the przewalski`s chromosomes (EPR23 and EPR24), hence it is possible to mate przewalski and domestic horse and to produce fertile offsprings (AHRENS and STRANZINGER, 2005).

\section{Cytogenetic map}

Physical identification of loci of interest can be achieved by fluorescence in situ hybridisation (FISH). The first fluorescence in situ hybridisation in the horse was reported by OAKENFULL et al. (1993) with the mapping of the alpha-globin gene complex to horse chromosome (ECA) 13. BREEN et al. (1997) localized the first equine markers when they mapped 18 microsatellites. RAUDSEPP et al. (1997) cytogenetically mapped genes to the genome of the donkey. LEAR et al. (2001), RAUDSEPP et al. (2002), GODARD et al. (2000) used goat BAC clones to localize 44 coding sequences on the equine FISH map. LINDGREN et al. (2001) localized another 13 genes by FISH and somatic cell hybrids. One of the first most extensive FISH-map included 136 genes (MILENKOVIC et al., 2002), and to this cytogenetic map further 165 genes were added by FISH and/or radiation hybrid (RH) mapping (PERROCHEAU et al., 2005). The equine gene map now contains 713 genes, 441 on the RH map, 511 on the cytogenetic and 238 on both maps. 
Several of gene groups attracted special interest for mapping in different animals, such as immunity-related genes: GUSTAFSON et al. (2003) constructed an ordered BAC contig map of the equine major histocompatibility complex (MHC) and TALLMADGE et al. (2003) mapped the ß2-microglobulin gene that is responsible for the light chain of the MHC to ECA1q23-q25. MUSILOVA et al. (2005) mapped another 19 horse immunity-related loci by FISH. NERGADZE et al. (2006) localized the IL8 gene on ECA3q14. Others mapped genes related to the bone-, cartilage- and collagene-metabolism. Genes eventually responsible for bone- or collagene-related hereditary diseases in the horse were mapped by HILLYER et al. (2005), MÜLLER et al. (2005), BÖNEKER et al. (2005) and DIERKS et al. (2006).

\section{Synteny and radiation hybrid maps}

Synteny mapping and radiation hybrid mapping in the horse work analogously to those in humans, but the utilization of these techniques began more than 20 years later than in humans. While there had been five synteny panels in the horse since 1992 (LEAR et al., 1992; WILLIAMS et al., 1993; BAILEY et al., 1995; RANEY et al., 1998), the most important one was the UC Davis panel generated by SHIUE et al. (1999). It included 450 markers and represents the origin for the developed horse-human comparative maps (CAETANO et al., 1999).

A 3000-rad panel was developed by KIGUWA et al. (2000). Preliminary comparative maps of horse chromosomes 1 to10 were created using this panel. A great progress was the more extensive 5000-rad whole-genome-radiation hybrid panel that was constructed using 92 horse x hamster hybrid cell lines and 730 equine markers (type I and type II markers) (CHOWDHARY et al., 2003). This panel was one of the most essential tools to construct high-resolution and comparative maps for ECA11 (CHOWDHARY et al., 2003), ECAX (RAUDSEPP et al., 2004), ECA17 (LEE et al., 2004), ECA22 (GUSTAFSON-SEABURY et al., 2005), ECA4 (DIERKS et al., 2006), equine homologs of HSA19 on ECA17, ECA10 and ECA21 (BRINKMEYERLANGFORD et al., 2005) and equine homologs of HSA2 on ECA6p, ECA15 and ECA18 (WAGNER et al., 2006).

\section{Comparative map}

Comparative maps between horse and human and horse and mouse are the most important ones. There also exist comparative maps between horse and other mammalians e.g., between horse and donkey (RAUDSEPP et al., 1997, 1999, 2001; RAUDSEPP and CHOWDHARY, 2001), horse and mountain zebra (RAUDSEPP et al., 2002) and E. caballus and E. przewalski (MYKA et al., 2003). Comparative chromosomal painting (Zoo-FISH) helps identifying conserved chromosomal segments among species. Reciprocal painting of chromosomes and segments was performed to compare the horse genome with that of the donkey (RAUDSEPP et al., 1996; CHOWDHARY et al., 1998; YANG et al., 2004).

One approach to localize genes and to expand the comparative gene map between horse and man is to pick genes or DNA-/RNA-sequences from genes physically mapped and cloned in humans for screening filters of a genomic horse BAC library. After verification of the selected gene sequence on the genomic equine BAC clone, FISH is used for mapping this BAC clone on horse metaphase spreads. There are three equine genomic BAC-libraries available: the equine BAC library of the Children`s 
Hospital of Oakland Research Institute, CHORI-241 (GODARD et al., 1998), one generated by the Texas A\&M University (TAMU) and the other by the Institut de la National Recherche Agronomique (INRA-LGBC library) (CHOWDHARY et al., 2003).

CAETANO et al. (1999) published an extensive comparative map between horse and man containing 68 equine type I loci. The most topical comparative map between horse, donkey and human was generated by cross-species painting (YANG et al., 2004). The human-donkey map was the first genome-wide comparative map between these species generated by chromosome painting. This horse-human comparative map agrees basically with the comparative map of CHOWDHARY et al. (2003), except from varying results especially for ECA1. For several horse chromosomes, detailed comparative maps have been developed. A detailed physical map of the equine Ychromosome was generated (RAUDSEPP et al., 2004) and compared to the human and other mammalian species with the result that the equine $\mathrm{Y}$-chromosome shows the most homology with the Y-chromosome of the pig. A comparative $\mathrm{RH}$ map for ECA17 was developed by LEE et al. (2004), and there exists a detailed RH map of ECA22 comparing the equine loci to human, dog, cat, bovids, elephant and bat, rodents, dolphins and other mammalians (GUSTAFSON-SEABURY et al., 2005). This map covered estimated $64 \mathrm{Mb}$ of physical length of chromosome 22 (831 cR) and the 83 markers had an average distance of $10 \mathrm{cR}$. It was remarkable, that the most common configuration for the ECA22 homologs consisted for Hartmann's zebra as expected, but also for carnivores, hippos, primates, rabbits, squirrels and bats. The conserved synteny between the compared animals can be taken as an indicator of the degree of putative ancestral relationship between the different species. BRINKMEYER-LANGFORD et al. (2005) compared equine homologs of HSA19 to other mammals using 89 loci for the 5000-rad-RH-panel and four loci for FISH. The homologs to HSA19 were localized on ECA7, 21 and 10. This comparison demonstrated an overview of the evolution of putative ancestral HSA19 chromosomal segments in more than 50 mammalian species.

PERROCHEAU et al. (2006) developed a medium density horse gene map using 323 genes evenly distributed over the human genome. They mapped 87 genes by FISH and 186 genes by the equine 5000-rad RH panel and thereby detected previously unknown homology between ECA27 and HSA8 as well as between ECA12p and HSA11p.

\section{Linkage map}

Genetic and physical assignment of equine microsatellites began almost ten years ago. BREEN et al. (1997) isolated 20 equine microsatellites from a genomic phage library and mapped them by linkage mapping and FISH. GODARD et al. (1997) assigned 36 new horse microsatellites, 11 of them from plasmid libraries and 25 from a cosmid library.

The first equine linkage map included 140 markers (LINDGREN et al., 1998) and a more extensive linkage map consisted of 161 loci in 29 linkage groups for 26 autosomes (GUERIN et al., 1999). The first map covering all autosomes and the sexchromosomes using 353 microsatellite-markers was generated by SWINBURNE et al. (2000). The microsatellites were mapped to 42 linkage groups and covered $1780 \mathrm{cM}$ of the horse genome.

A second generation linkage map was published by the International Equine Gene Mapping Workshop (GUERIN et al. 2003). This linkage map was based on testing 
503 half-sibling offspring from 13 sire families. The map included 344 markers in 34 linkage groups representing all 31 autosomes, but neither the $\mathrm{X}$ - nor the $\mathrm{Y}$ chromosome. The linkage groups covered $2262 \mathrm{cM}$ with an average interval between loci of $10.1 \mathrm{cM}$, ranging from 0 to 38.4. Another 61 new horse microsatellite loci were assigned by SWINBURNE et al. (2003). TOZAKI et al. (2004) reported the characterization of 341 newly isolated microsatellite markers of which 256 were assigned to equine chromosomes.

PENEDO et al. (2005) added 359 microsatellites to the second generation linkage map. Alltogether, this linkage map consisted of 766 markers assigned to the 30 autosomes and the X-chromosome spanning $3740 \mathrm{cM}$ with an average marker density of 6.3 cM. SWINBURNE et al. (2006) generated a linkage map including 742 markers in 32 linkage groups according to the 31 autosomes and the X-chromosome. All linkage groups together span $2772 \mathrm{cM}$ with an average interval of $3.7 \mathrm{cM}$ between the markers.

\section{Chromosomal abnormalities}

There exist several chromosomal abnormalities in the horse. Of great interest and therefore well analyzed are those concerning the sex-chromosomes and influencing the fertility of mares:

The most common abnormality in mares, X0 Gonadal Dysgenesis ( $\mathrm{X}$ monosomy), is characterised by the lack of one X-chromosome $(63, \mathrm{X} 0)$ and was primarily described by HUGHES et al. (1975). This defect was accompanied with infertility of the affected mare. POWER (1986) reported another abnormality in horses, the XY Gonadal Dysgenesis. The affected horses ' phenotype is female, but their genotype is 64,XY leading to infertility (BOWLING et al., 1987). There exist also infertile mares with the genotype 65,XXX (CHANDLEY et al., 1975). KAKOI et al. (2005) published a statistical evaluation of sex chromosome abnormalities and analyzed data of 17471 light-breed foals with the result that $0.15 \%$ of the analyzed population showed an XO-, $0.02 \%$ an XXY- (and/ or mosaics/chimaeras) and 0.01\% an XXX-genotype.

Unlike the sex chromosomes, chromosomal abnormalities of the autosomes are rarely encountered. Cases of trisomy are similar to human Downs and associated with mental retardation failure to thrive (LEAR et al., 1999).

\section{Coat colours}

There exist several genetically characterized major genes that influence the coat colour of a horse: Agouti-gene, Extension-gene, Cream dilution gene, Tobiano-gene, Whitegene, Greying hair-gene, Dun-gene, Roan-gene, Sabino-gene, Silver-gene, and the Leopard Complex-gene. Knowledge about the inheritance of coat colours is very important for the breeders, so it is comparatively well explorated and for several genes exist gene tests, too. Chromosomal locations and mutations of genes associated with equine coat colours are summarized in Table.

The White-gene and the Greying hair-gene can mask all the other coat colour genes, so they are mentioned first.

White-gene (W-gene) and Sabino spotting

Horses with the dominant allele "W" lack pigment in skin and hair, so their coat colour is white at birth, but eyes are dark or sometimes blue. The $\mathrm{W}$-mutation was mapped to 
a region of ECA3q22 where the equine KIT gene is located (MAU et al., 2004). The homozygous "WW" is lethal at a very early stage of pregnancy as it is in mice, too. Since the action of the dominant white allele seems not always to be fully penetrant, some horses homozygously "WW" are born alive with the phenotype of sabino spotting. All non-white horses are homozygous recessive "ww". In contrast to the greying gene, horses with the dominant "W" are not able to produce any pigment, white horses with the " $G$ ”-gene instead can produce pigment but lose their pigment with aging.

Sabino pattern is characterized by irregulary bordered white patches on the lower limbs and face and often includes belly and interspersed white hairs on the midsection. Sabino spotting is found in many light horse breeds such as Tennessee walking horse, Missouri Foxtrotter, Shetland pony and American Paint Horse. A single nucleotide exchange in the 3'-splice site of intron 16 of the equine KIT gene causes a partial skipping of exon 17 and the Sabino spotting (BROOKS and BAILEY, 2005).

Furthermore, close association between KIT polymorphisms and roan coat colour was detected in horses (MARKLUND et al., 1999).

\section{Greying-gene (G-gene)}

The dominant allele " $G$ " is responsible for progressive greying in hairs. If a foal that possesses the allele " $G$ " is born coloured it will progressively turn white as an aged animal. The Grey-locus was mapped to ECA25 by SWINBURNE et al. (2002) and by HENNER et al. (2002). The mapping of the G-gene was of particular importance because the Grey-gene and the appearance of melanomas in horses are associated: grey horses get melanomas with a frequency of at least $80 \%$ in horses older than 10 years whereas melanomas are rare in non-grey horses. SWINBURNE et al. (2002) localized the G-locus $13 \mathrm{cM}$ proximal of the marker TKY316 and $17 \mathrm{cM}$ distal of the marker UCDEQ464 using a whole genome scan.

PIELBERG et al. (2005) refined the grey-locus to a region smaller than $6.9 \mathrm{Mb}$ on ECA25 using comparative mapping to mouse and human. In this refined region, no obvious candidate genes for pigmentation disorders could be identified. Several possible candidate genes responsible for different coat colours including agoutisignaling-protein (ASIP), melanocortin-1-receptor (MC1R), tyrosinase-related protein 1 (TYRP1) and silver homolog (SILV, PMEL17) had been excluded before (RIEDER et al., 2001; LOCKE et al., 2002).

\section{Agouti-gene (A-gene)}

The Agouti locus with the dominant " $A$ " and recessive "a" allele is responsible for the distribution pattern of black hair. The interaction with the extension-gene is responsible if the horse is bay or black: A horse that is homozygous recessive "aa" will be black if it also possesses a dominant " $E$ " allele. If a horse possesses at least one " $A$ " allele together with the "E" allele, it will be bay. However, if a horse is homozygous recessive "ee", it will look sorrel or chestnut, irrespective if it carries an " $A$ " or "a". This is important for the breeders, because it is possible that a sorrel or chestnut horse can also produce blacks. RIEDER et al. (2001) characterized equine MC1R (melanocortin-1-receptor) and ASIP (agouti signaling protein), and completed a partial sequence of TYRP1. They detected an 11-bp deletion in exon 2 (ADEx2) of ASIP which was completely associated with horse recessive black coat color in horses of 9 
different breeds. The frameshift initiated by ADEx2 was supposed to act as a loss-offunction ASIP mutation.

\section{Extension gene (E-gene)}

The Extension locus controls the expression of black pigment in horses. The equine melanocyte stimulating hormone receptor (MC1R) on ECA3 encodes the Extension locus (MARKLUND et al., 1996). A missense mutation in MC1R was associated with light colour, whereas the wildtype allele corresponded to dark pigmentation. A black or bay horse possesses at least one "E" allele. A horse that is homozygous "ee" is either chestnut or sorrel. For horse breeders where black colour is valued, it is important, if a horse is homozygous "EE", because that means that it will never have a chestnut or sorrel foal.

\section{Cream dilution gene (C-gene)}

The dominant " $C$ " allele causes a reduction in red pigment in hairs. A sorrel horse inheriting one " $\mathrm{C}$ " allele is palomino (ee/Cc), a sorrel inheriting " $\mathrm{C} / \mathrm{C}$ " is cremello (ee/CC). A bay horse inheriting one "C" allele is buckskin (E-/Cc) and a horse homozygous for " $\mathrm{C}$ ” is a perlino (E-/CC). It is also possible that grey or dun horses carry the "C" allel. The C-locus was localized to ECA21 and TYR (tyrosinase) could be excluded as candidate for the cream dilution gene (LOCKE et al., 2001). MARIAT et al. (2003) identified the causal mutation similarly to mice and humans in exon 2 of the membrane associated transporter protein (MATP) gene mapping to ECA21p17. A gene test based on this $\mathrm{G}$ to $\mathrm{A}$ transition could be developed to control if a horse carries a dominant " $\mathrm{C}$ ” allele.

\section{Tobiano-gene (To-gene)}

The "To" allele is dominantly inherited and is responsible for white spotting characterized by distinct borders crossing the dorsal midline and including at least one if not all four limbs. There was identified a MSPI polymorphism for the Tobiano-locus in intron 13 of the equine homologue of the proto-oncogene c-kit (KIT) gene (KM1 locus) which is strongly associated with the Tobiano gene but not causative (BROOKS et al., 2002). If a horse does not possess the Tobiano-allele, the test result will be designated KM0/KM0. If a horse carries one "To" allele, it will be tested KM0/KM1, and if the test is KM1/KM1, the horse is probably a homozygous Tobiano. However, solid-coloured horses can also possess the KM1 allele. This test is useful for breeders valuing homozygous Tobianos, because they will always produce spotted foals.

\section{Silver-gene (Z-gene)}

A mutation in the Silver (PMEL17) gene had recently been identified that produces in black horses a chocolate coat colour with flaxen mane and tail and in bay horses lightened coat colour in lower legs and flaxen mane and tail (BRUNBERG et al., 2006). This mutation has no effect on chestnut-coloured horses. A missense mutation in exon 11 changing arginine to cysteine (Arg618Cys) was likely to be causative as complete association with the Silver phenotype was observed across several horse breeds. A further silent mutation in intron 9 was also completely associated with the Silver phenotype. 


\section{Appaloosa coat colour}

TERRY et al. (2004) investigated the appaloosa coat colour which is characterized by several different spotting patterns ranging from a few white specks on the rump to an almost completely white animal (Table). They excluded the KIT gene as possible candidate gene causing $\mathrm{Rw}$ colour pattern in mice and also the candidate genes microphthalmia-associated transcription factor (MITF) and mast cell growth factor (MGF) (TERRY et al., 2001, 2002). They found that the autosomal incompletely dominant gene LP (leopard complex) responsible for the appaloosa coat pattern in horses mapped to ECA1q (TERRY et al., 2004).

Table

Molecular genetic characterization of coat colour loci in horse (Molekulargenetische Charakterisierung von Farbgenorten beim Pferd)

\begin{tabular}{|c|c|c|c|c|}
\hline Locus & Gene & ECA & Mutation & Reference \\
\hline Agouti & ASIP & 22q15-q16 & 11 bp deletion & RIEDER et al. (2001) \\
\hline Extension & MC1R & 3p12 & $\begin{array}{l}\mathrm{C}>\mathrm{T} \text { missense } \\
\text { mutation }\end{array}$ & MARKLUND et al. (1996) \\
\hline Cream & MATP & 21p17 & $\begin{array}{l}\text { G>A missense } \\
\text { mutation }\end{array}$ & MARIAT et al. (2003) \\
\hline Sabino & KIT & $3 q 22$ & $\begin{array}{l}\mathrm{T}>\mathrm{A} \text { mutation } \\
\text { (splice mutation) }\end{array}$ & BROOKS and BAILEY (2005) \\
\hline Tobiano & KIT & $3 q 22$ & $\begin{array}{l}\mathrm{C}>\mathrm{G} \text { missense } \\
\text { mutation }\end{array}$ & BROOKS et al. (2002) \\
\hline Silver & PMEL17 & $6 q 23$ & $\begin{array}{l}\mathrm{C}>\mathrm{T} \text { missense } \\
\text { mutation }\end{array}$ & BRUNBERG et al. (2006) \\
\hline
\end{tabular}

ECA: Equus caballus autosome.

Equine genetic diseases and the development of gene tests

The most important information breeders take from gene investigation are probably new results as to diseases or phenotypic features.

While inheritance of colours is usually comparatively simple with different alleles that are either dominant or recessive responsible for all colours, investigation of inheritance of diseases is often much more complicated, for example multifactorial and influenced by lots of different genes. There are 188 diseases reported in the horse that are discussed to be inherited. For 20 well-explorated diseases only a single locus is responsible for the appearance.

This is probably one of the reasons for the fact that there are only a few gene tests available for important diseases but for many of the possibly inherited diseases in the horse the inheritance is still unknown.

\section{Monogenic equine diseases}

\section{Lethal White Foal Syndrome (LWFS)}

The Lethal White Foal Syndrome is observed in horse breeds with white coat spotting patterns called overo, e.g., in Paints and Pintos. Affected foals are almost completely white and die shortly after birth due to severe intestinal blockage resulting from a lack of nerve cells in the distal portion of the large intestine (aganglionic megacolon). The disease is similar to Hirschsprung disease in humans. As the Hirschsprung disease is caused by a mutation in the endothelian B receptor gene (EDNRB), METALLINOS et al. (1998) investigated the influence of the EDNRB in horses with Lethal White Foal Syndrome and found an association between a missense mutation in the EDNRB-gene 
and the appearance of LWFS like in humans for the Hirschsprung disease. YANG et al. (1998) could show that a dinucleotide TC>AG mutation was associated with LWFS when homozygous and with the overo phenotype when heterozygous.

Herlitz junctional epidermolysis bullosa (epitheliogenesis imperfecta)

The pathological signs of epitheliogenesis imperfecta closely match a similar disease in humans known as Herlitz junctional epidermolysis bullosa, which is caused by a mutation in one of the genes (LAMA3, LAMB3 and LAMC2) coding for the subunits of the laminin 5 protein. Herlitz junctional epidermolysis bullosa (HJEB) is a lethal disease that causes blistering of the skin and mouth epithelia, and sloughing of hooves in newborn foals, especially in American Saddlebred horses and Belgian draft horses (JOHNSON et al., 1998). Pedigree studies demonstrated that the trait followed a monogenic autosomal recessive inheritance pattern and a genetic mapping study revealed that HJEB in American Saddlebred horses was linked to microsatellites on ECA8q where LAMA3 is also located (LIETO and COTHRAN, 2003). SPIRITO et al. (2002) detected a cytosine insertion in exon 10 in the LAMC2 gene as being responsible for HJEB in Belgian draft horses and BAIRD et al. (2003) developed a gene test that works with hair of the horses and is now available for owners of registered horses. The same mutation was found to be associated with the same condition in the French draft horse breeds, Trait Breton and Trait Comtois (MILENKOVIC et al., 2003).

\section{Hyperkalemic periodic paralysis}

Hyperkalemic periodic paralysis (HYPP) is an inherited disease of the muscles that causes attacks of paralysis that can lead to sudden death that especially affects American Quarter horses. It is inherited as an autosomal codominant genetic defect so that heterozygous horses are affected, too (ZEILMANN, 1993). HYPP is the result of a missense mutation of the gene encoding the $\alpha$-chain of the adult muscle sodium channel. RUDOLPH et al. (1992) described the point mutation in transmembrane domain IVS3 that is responsible for the occurrence of the disease. Even though the attacks can be treated with azetazolamide (KOLLIAS-BAKER, 1999) and the disease will not always lead to death, it is useful to test horses if they are carriers or not.

\section{Severe Combined Immunodeficiency (SCID)}

SCID is an inherited disease known in different species that always causes an early death of affected animals because of the incapability to generate antigene-specific immune responses; there exists a comparative study between the different mechanisms that lead to SCID in humans, mice, horses and dogs (PERRYMAN, 2004). SCID is recessively inherited in Arabian horses. Horses affected with SCID cannot react in a natural way of protection against diseases. They do not develop the necessary active protection reactions because they lack intact lymphocytes. Due to this reason, affected foals will not become older than six months. SHIN et al. (1997) tested candidate genes from the mouse and could show that SCID is caused by a frameshift mutation in the gene for DNA-dependent protein kinase catalytic subunit (DNA-PK) mapping to horse chromosome 9. This mutation results in the lack of a full-length kinase.

\section{Glycogen Branching Enzyme Deficiency (GBED)}

GBED is a glycogene storage disease similar to the human glycogen storage disease type IV. The disease is lethal for the affected foals with a great variability of 
symptoms ranging from abort or stillbirth until being euthanized due to weakness. VALBERG et al. (2001) described the disease in American Quarter horses. Common to GBED are the accumulation of unbranched polysaccharides in tissues and a profound decrease of glycogen branching enzyme activity in cardiac and skeletal muscle as well as in liver and peripheral blood cells of affected foals. The pedigree analysis supported an autosomal recessive mode of inheritance.

WARD et al. (2003) mapped the GBE1 gene to ECA26q12-q13, and later on, detected the C- to A-mutation at base 102 of the GBE1 gene causing the disease (WARD et al., 2004). An autosomal recessive mode of inheritance was confirmed. It is now possible to test horses whether they are carriers of the GBE1 allele.

\section{Osteochondrosis (OC)}

Genetically complex equine diseases

Osteochondrosis (OC) is a developmental orthopaedic disorder frequently observed in young horses (VAN DE LEST et al., 1999). Signs of osteochondrosis are lesions of the cartilage in the joints like subchondral fractures, subchondral cysts, wear lines, chondromalacia, cartilage flaps and joint mice or free joint bodies (chips). Hereditary factors play an important part in the pathogenesis of OC. An optimized microsatellite marker set for complete genome scans in horses was developed including 155 highly polymorphic markers equally distributed at a distance of about $20 \mathrm{cM}$. Data from 14 half-sib families of Hanoverian Warmblood horses were analysed using this marker set to detect quantitative trait loci (QTL) with significant influence on the development of OC (BÖNEKER et al., 2006; DIERKS et al., 2006). QTL for osteochondrosis in fetlock and hock joints were found on horse chromosomes 2, 3, 4, 5, 15, 16, 19, and 21. In a population of South German coldblood horses a further whole genome scan for OC in fetlock and hock joints was carried out (WITTWER et al., 2006; WITTWER and DISTL, 2006). In total, 17 chromosome-wide significant QTL were found on different equine chromosomes with influence on the development of OC in fetlock and hock joints.

\section{Navicular disease}

Navicular disease (navicular syndrome or podotrochlosis) is a chronic and usually progressive, degenerative alteration of the equine podotrochlea (RIJKENHUIZEN, 1989). Pathological alterations can primarily affect the navicular bone (os sesamoideum distale), the navicular bursa (bursa podotrochlearis) or the distal end of the deep digital flexor tendon. The disease may be part of the osteoarthritis complex (SVALASTOGA and SMITH, 1983). A microsatellite marker set to be applied in Hanoverian warmblood horses for a whole genome scan was prepared and then a whole genome scan in 144 descendants of 17 Hanoverian warmblood stallions was performed. The genotyped horses were randomly sampled from the whole Hanoverian warmblood breeding district. QTL on different horse chromosomes were identified such as on ECA2, 3, 4, and 10 (DIESTERBECK et al., 2006). According to SVALASTOGA and SMITH (1983) increased bone marrow pressure and lengthened contrast passage indicate similarities between osteoarthritis (OA) in humans and navicular disease in horses. About 50 different positional candidate genes have been reported for OA in humans. These candidate genes encode different types of collagens, hormone receptors and interleukin receptors, growth factors and metalloproteinases. 
About 13,966 equine cartilage expressed sequence tags (ESTs) and further 23,171 ESTs from other cDNA libraries as well as BAC end sequences or whole genome sequences can be used for identification of single nucleotide polymorphisms in functional and positional candidate genes. However, since navicular disease does not occur in humans, it is not clear whether genes for OA are suitable candidates for navicular bone disease in horses.

\section{Temperament}

Temperament is considered important in horses as optimal performance is related with a good temperament. The neurotransmitter-related dopamine D4 receptor (DRD4) gene harbours many polymorphism in the coding region and among them, the variable number of tandem repeats polymorphisms consisting of a 48-bp repeat unit was shown to be associated with novelty-seeking in humans (BENJAMIN et al., 1996; EBSTEIN et al., 1996). In horses, this part of DRD4 included repeats of an 18-bp repeat unit (HASEGAWA et al., 2002). Two temperament scores, curiosity and vigilance were associated with a single nucleotide polymorphism (A $>$ G substitution) of DRD4 but no difference in the number of repeats among the 136 two-year-old thoroughbred horses was found (MOMOZAWA et al., 2005). Horses without the A allele had higher curiosity and lower vigilance scores than those with the A allele.

Polymorphisms of the serotonin transporter (SLC6A4) gene were screened for associations with an anxiety score in 67 Thoroughbred horses (MOMOZAWA et al., 2006). However, no significant associations could be identified in this study.

\section{Stallion fertility}

Seminal plasma proteins that are produced by the epididymis and the accessory glands play an important role in sperm maturation. Some of these proteins bind to spermatozoa and act as binding partners in the female genital tract and others are required to suppress adverse immune reactions directed against spermatozoa. Among the seminal plasma proteins, cystein-rich secretory protein 3 (CRISP3) is found in large amounts in the seminal plasma of stallions (SCHAMBONY et al., 1998). Association studies for CRISP3 polymorphisms in 107 Hanoverian stallions revealed a significant influence on fertility at artificial insemination of mares (HAMANN et al., 2006). Stallions being heterozygous for an E208K mutation within the CRISP3 gene had less insemination success than those without this mutation or homozygous for this mutation.

\section{Conclusions and perspectives}

There has been great progress in the horse genome investigation especially during the last ten years, but compared to the human genome or to animals like the mouse, the horse gene map still shows many unexplored areas.

For the coat colours, the inheritance of the major colours is already resolved, but for several possibly inherited diseases the mode of inheritance is still not detected despite of intensive investigation in the last years, as for example for the appearance of "parrot mouth”, "hyperelastosis cutis”, "laminitis”, “osteochondrosis” and many more. It is always difficult if there are no suitable candidate genes from the human because no equivalent diseases exist in human. Another problem is that many diseases are not 
only characterized by a single mutation or a simple dominant or recessive mode of inheritance but are multifactorial and many different genes or environmental effects like feeding or movement influence the appearance of these diseases.

The ongoing refinement of the comparative map between horse and human plays an important role in genomic studies in the horse: Without the generation of tools like the 5000-rad-RH-panel by CHOWDHARY et al. (2003) it would not be possible to map new loci as accurately as they can be localized today. Laborious methods like the fluorescence in-situ hybridization (FISH) are increasingly eclipsed by methods that are more timesaving and that lead to more new results in one experiment, like the radiation hybrid panel mapping $(\mathrm{RH})$.

Horse genome sequencing, funded by the National Human Genome Research Institute, had started in February 2006 and the sequencing of the about 2.7 billion DNA bases is nearly complete. A whole genome shotgun approach is being used for sequencing a female thoroughbred named "Twilight". A high-quality genome sequence of Equus caballus will be elaborated together with an analysis of sequence variation of 100,000 randomly chosen DNA segments from mares of seven additional breeds. Breeds selected for this single nucleotide polymorphisms (SNPs) analysis included thoroughbred, Quarterhorse, Arabian horse, American Standardbred pacer, Akalteke, Andalusian and Icelandic horse. More than one million SNPs should be identified. The horse genome project has emerged from an ongoing effort to highlight the most evolutionarily conserved segments of the human genome by identifying genetic similarities between several different mammalian genomes and human genome. A high-quality horse genome sequence and the large catalogue of SNPs will be the key to identify the genetic contributions to the aetiopathogenesis of diseases, physiological and pathological processes and to the athletic performance of horses in sports, agriculture and transportation.

\footnotetext{
References

AHRENS, E.; STRANZINGER G.:

Comparative chromosomal studies of E. caballus (ECA) and PRZEWALSKII, E.: (EPR) in a female F1 hybrid. J. Anim. Breed. Genet., 122, Suppl. 1, (2005), 97-102

BAILEY, E.; GRAVES, K.T.; COTHRAN, E.G.; REID, R.; LEAR, T.L.; ENNIS, R.B.:

Synteny-mapping horse microsatellite markers using a heterohybridoma-panel. Anim. Genet., 26, (1995), 177-180
}

BAIRD, J.D.; MILLON, L.V.; DILEANIS, M.C.; PENEDO, M.C.T.; CHARLESWORTH, A.; SPIRITO, F.; MENEGUZZI, G.: Junctional epidermolysis bullosa in Belgian draft horses. $49^{\text {th }}$ Ann. Convent. Am. Ass. Equine Pract., (2003), New Orleans, Lousiana

BENJAMIN, J.; LI, L.; PATTERSON, C.; GREENBERG, B.D.; MURPHY, D.L. et al.: Population and familial association between the D4 dopamine receptor gene and measures of Novelty Seeking. Nat. Genet., 12, (1996), 81-84

BETHESDA, M.:

Genome sequence of the nematode C. elegans: A platform for investigating biology. The Genome Sequencing Consortium. Science, 282, (1998), 2012-2021

BETHESDA, M.: Dog genome assembled. NIH News Advisory, (2004), 14/07/2004

BÖNEKER, C.; KUIPER, H.; WÖHLKE, A.; DRÖGEMUELLER, C.; CHOWDHARY, B.P.; DISTL, O.: Assignment of the COL16A1 gene to equine chromosome 2p15.1-p15.3 by FISH and confirmation by RH mapping. Anim. Genet., 36, (2005), 262-263

BÖNEKER, C.; LÖHRING, K.; WITTWER, C.; DRÖGEMÜLLER, C., DISTL O.: Genome-wide search for markers associated with osteochondrosis in Hanoverian Warmblood horses. (2006), Submitted

BOWLING, A.T.; MILLON, L.; HUGHES, J.P.: 
An update of chromosomal abnormalities in mares. J. Reprod. Fertil. Suppl., 35, (1987), 149-155

BREEN, M.; LINDGREN, G.; BINNS, M.M.; NORMAN, J.; IRVIN, Z.; BELL, K.; SANDBERG, K.;

ELLEGREN, H.:

Genetical and physical assignments of equine microsatellites- First integration of anchored markers in horse genome mapping. Mamm. Genome, 8, (1997), 267-273

BRINKMEYER-LANGFORD, C.; RAUDSEPP, T.; LEE, E.-J.; GOH, G.; SCHÄFFER, A.A.; AGARWALA,

R.; WAGNER, M.L.; TOZAKI, T.; SKOW, L.C.; WOMACK, J.E.; MICKELSON, J.R.; CHOWDHARY, B.P.: A high-resolution physical map of equine homologs of HAS 19 shows divergent evolution compared with other animals. Mamm. Genome, 16, (2005), 631-649

BROOKS, S.A.; TERRY, R.B.; BAILEY, E.:

A PCR-RFLP for KIT associated with tobiano spotting pattern in horses. Anim. Genet., 33, (2002), 301303

BROOKS, S.A.; BAILEY, E.:

Exon skipping in the Kit gene causes a Sabino spotting pattern in horses. Mamm. Genome, 16, (2005), 893-902

BRUNBERG, E.; ANDERSSON, L.; COTHRAN, G.; SANDBERG, K.; MIKKO, S.; LINDGREN, G.: A missense mutation in PMEL17 is associated with the Silver coat color in the horse. BMC Genetics, 7 (2006), 46

CAETANO, A.R.; SHIUE, Y.L.; LYONS, L.A.; O’BRIEN, S.F.; LAUGHLIN, T.F.; BOWLING, A.T.; MURRAY, J.D.:

A comparative gene map of the horse (Equus caballus). Genome Res., 9, (1999), 1239-1249

CHANDLEY, A.C.; FLETCHER, J.; ROSSDALE, P.D.; PEACE, C.K.; RICKETTS, S.W.; MC ENERY, R.J.; THORNE, J.P.; SHORT, R.V.; ALLEN, W.R.:

Chromosome abnormalities as a cause of infertility in mares. J. Reprod. Fertil. Suppl., 23, (1975), 377383

CHOWDHARY, B. P.; RAUDSEPP, T.; GUAN, X.Y.; ZHANG, H.G.:

Zoo-FISH with microdissected arm specific paints for HSA 2, 5, 6, 16, and 19 refines known homology with pig and horse chromosomes. Mamm. Genome, 9, (1998), 44-49

CHOWDHARY, B.P.; RAUDSEPP, T.; FRONICKE, L.; SCHERTHAN, H.:

Emerging patterns of comparative genome organization in some mammalian species as revealed by zooFISH. Genome Res., 8, (1998), 577-589

CHOWDHARY, B.P.; RAUDSEPP, T.; HONEYCUTT, D.; OWENS, E.K.; PIUMI, F.; GUERIN, G.; MATISE, T.C.; KATA, S.R.; WOMACK, J.E.; SKOW, L.C.:

Construction of a 5000 (rad) whole-genome radiation hybrid panel in the horse and generation of a comprehensive and comparative map for ECA 11. Mamm. Genome, 13, (2002), 89-94

CHOWDHARY, B.P.; RAUDSEPP, T.; KATA, S.R.; GOH, G.; MILLON, L.V.; ALLAN, V.; PIUMI, F.; GUERIN, G.; SWINBURNE, J.; BINNS, M; LEAR, T.L.; MICKELSON, J.; MURRAY, J.; ANTCZAK, D.F.;

WOMACK, J.E.; SKOW, L.C.:

The first-generation whole-genome radiation hybrid map in the horse identifies conserved segments in human and mouse genomes. Genome Res., 13, (2003), 742-751

CHOWDHARY, B.P.; BAILEY, E.: Equine genomics: galloping to new frontiers. Cytogenet. Genome Res., 102, (2003), 184-188

DIERKS, C.; MÖMKE, S.; DRÖGEMÜLLER, C.; LEEB, T.; CHOWDHARY, B.P.; DISTL, O.:

A high-resolution comparative radiation hybrid map of equine chromosome 4q12-q22 with human chromosome 7p and 7q. Anim. Genet., 37 (2006) , 513-517

DIESTERBECK, U.S.; HERTSCH, B.; DISTL, O.:

Genome-wide search for microsatellite markers associated with radiological alterations in the navicular bone of Hanoverian warmblood horses. (2006), Submitted

EBSTEIN, R.P.; NOVIK, O.; UMANSKY, R.; PRIEL, B.; OSHER, Y. et al.:

Dopamine D4 receptor (D4DR) exon III polymorphism associated with the human personality trait of Novelty Seeking. Nat. Genet., 12, (1996), 78-80

FADIEL, A.; ANIDI, I.; EICHENBAUM, K.D.:

Farm animal genomics and informatics: an update. Nucleic Acids Research, 33, (2005), 6308-6318

GODARD, S.; VAIMAN, D.; OUSTRY, A.; NOCART, M.; BERTAUD, M.; GUZYLACK, S.; MERIAUX,

J.C.; CRIBIU, E.P.; GUERIN, G.:

Characterization, genetic and physical mapping analysis of 36 horse plasmid and cosmid-derived microsatellites. Mamm. Genome, 8, (1997), 745-750

GODARD, S.; SCHIBBLER, L.; OUSTRY, A.; CRIBIU, E.P.; GUERIN, G.:

Construction of a horse BAC library and cytogenetical assignment of 20 type I and type II markers. Mamm. Genome, 9, (1998), 633-637

GODARD, S.; VAIMAN, A.; SCHIBLER, L.; MARIAT, D.; VAIMAN, D.; CRIBIU, E.P.; GUERIN, G.: 
Cytogenetic localization of 44 new coding sequences in the horse. Mamm. Genome, 11, (2000), 10931097

GUERIN, G.; BAILEY, E.; BERNOCO, D.; ANDERSON, I.; ANTCZAK, D.F.; BELL, K.; BINNS, M.M.; BOWLING, A.T.; BRANDON, R.; CHOLEWINSKI, G.; COTHRAN, E.G.; ELLEGREN, H.; FORSTER, M.; GODARD, S.; HORIN, P.; KETCHUM, M.; LINDGREN, G.; MCPARTLAN, H.; MERIAUX, J.C.; MICKELSON, J.R.; MILLON, L.V.; MURRAY, J.; NEAU, A.; ROED, K.; ZIEGLE, J. et al.:

Report of the International Equine Gene Mapping Workshop: male linkage map. Anim. Genet., 30, (1999), 341-354

GUERIN, G.; BAILEY, E.; BERNOCO, D.; ANDERSON, I.; ANTCZAK, D.F.; BELL, K.; BIROS, I.; BJORNSTAD, G.; BOWLING, A.T.; BRANDON, R.; CAETANO, A.R.; CHOLEWINSKI, G.; COLLING, D.; EGGLESTON, M.; ELLIS, N.; FLYNN; J.; GRALAK, B.; HASEGAWA, T.; KETCHUM, M.; LINDGREN, G.; LYONS, L.A.; MILLON, L.V.; MARIAT, D.; MURRAY, J.; NEAU, A.; ROED, K.; SANDBERG, K.; SKOW, L.C.; TAMMEN, I.; TOZAKI, T.; VAN DYK, E.; WEISS, B.; YOUNG, A.; ZIEGLE J.:

The second generation of the International Equine Gene Mapping Workshop half-sibling linkage map. Anim. Genet., 34, (2003), 161-168

GUSTAFSON, A.L.; TALLMADGE, R.L.; RAMLACHAN, N.; MILLER, D.; BIRD, H.; ANTCZAK, D.F.; RAUDSEPP, T.; CHOWDHARY, B.P.; SKOW, L.C.:

An ordered BAC contig map of the equine major histocompatibility complex. Cytogenet. Genome Res., 102, (2003), 189-195

GUSTAFSON-SEABURY, A.; RAUDSEPP, T.; GOH, G.; KATA, S.R.; WAGNER, M.L.; TOZAKI, T.; MICKELSON, J.R.; WOMACK, J.E.; SKOW, L.C.; CHOWDHARY, B.P.:

High-resolution RH map of horse chromosome 22 reveals a putative ancestral vertebrate chromosome. Genomics, 85, (2005), 188-200

HAMANN, H.; SIEME, H.; MERTENS, U.; DISTL, O.; LEEB, T.:

A polymorphism within the equine CRISP3 gene is associated with stallion fertility in Hanoverian warmblood horses. (2006), Submitted

HASEGAWA, T.; SATO, F.; ISHIDA, N.:

Determination and variability of nucleotide sequences for D4 dopamin receptor genes (DRD4) in genus equus. J. Equine Sci., 13, (2002), 57-62.

HELMINEN, H.J.; SÄÄMÄNEN, A.-M.; SALMINEN, H.; HYTTINEN, M.M.:

Transgenic mouse models for studying the role of cartilage macromolecules in osteoarthritis. Rheumatology, 41, (2002), 848-856

HENNER, J.; PONCET, P.A.; GUERIN, G.; HAGGER, C.; STRANZINGER, G.; RIEDER, S.:

Genetic mapping of the (G)-locus, responsible for the coat color phenotype "progressive greying with age” in horses (Equus caballus). Mamm. Genome, 13, (2002), 535-537

HILLYER, L.L.; PETTITT, L.A.; DEBENHAM, S.L.; SWINBURNE, J.E.; BINNS, M.M.; PRICE, J.S.: Equine microsatellites associated with the COMP, LRP5 and COL1A1 genes. Anim. Genet., 36, (2005), 261-262

HUGHES, J.P.; BENIRSCHKE, K.; KENNEDY, P.C.: Gonadal dysgenesis in the mare. J. Reprod. Fertil. Suppl., 23, (1975), 385-390

HU, J.; MUNGALL, C.; LAW, A.; PAPWORTH, R.; NELSON, J.P.; BROWN, A.; SIMPSON, I.; LECKIE, S.; BURT, D.W.; HILLYARD, A.L.; ARCHIBALD, A.L.: The ARKdb: genome databases for farmed and other animals. Nucleic Acids Res., 29 (2001), 106-110

JOHN, H.A.; BIRNSTEIN, M.L.; JONES, K.W.: RNA-DNA hybrids at the cytological level. Nature, 223, (1969), 582-587

JOHNSON, G.C.; KOHN, C.W.; JOHNSON, C.W.; GARRY, F.; SCOTT, D.; MARTIN, S.: Ultrastructure of junctional epidermolysis bullosa in Belgian foals. J. Comp. Pathol., 99, (1998), 329336

KAKOI, H.; HIROTA, K.; GAWAHARA, H.; KUROSAWA, M.; KUWAJIMA, M.: Genetic diagnosis of sex chromosome aberrations in horses based on parentage test by microsatellite DNA and analysis of X- and Y-linked markers. Equine vet J., 37, (2005), 143-147

KIGUWA, S.L.; HEXTALL, P.; SMITH, A.L.; CRITCHER, R.; SWINBURNE, J.; MILLON, L.; BINNS, M.M.; GOODFELLOW, P.N.; MCCARTHY, L.C.; FARR, C.J.; OAKENFULL, E.A.:

A horse whole-genome-radiation hybrid panel: chromosome 1 and 10 preliminary maps. Mamm. Genome, 11, (2000), 803-805

KOLLIAS-BAKER, C.: Therapeutics of musculoskeletal disease in the horse. Vet. Clin. North Am. Equine Pract., 15, (1999), 589-602

LEAR, T.L.; TREMBICKI, K.A.; ENNIS, R.B.:

Identification of equine chromosomes in horse $\mathrm{x}$ mouse somatic cell hybrids. Cytogenet. Cell Genet., 61, (1992), 58-60

LEAR, T.L.; COX, J.H.; KENNEDY, G.A.: 
Autosomal trisomy in a thoroughbred colt: 65, XY, +31. Equine Vet J., 31, (1999), 85-88

LEAR, T.L.; BRANDON, R.; PIUMI, F.; TERRY, R.R.; GUERIN, G.; THOMAS, S.; BAILEY, E.:

Mapping 31 horse genes in BACs by FISH; identification of chromosomal rearrangements and conserved synteny relative to the human gene map. Chrom. Res., 9, (2001), 261-262

LEE, E.J.; RAUDSEPP, T.; KATA, S.R.; ADELSON, D.; WOMACK, J.E.; SKOW, L.C.; CHOWDHARY, B.P.:

A 1.4-MB interval RH map of horse chromosome 17 provides detailed comparison with human and mouse homologues. Genomics, 83, (2004), 203-215

LIETO, L.D.; COTHRAN, E.G.:

The epitheliogenesis imperfecta locus maps to equine chromosome 8 in American Saddlebred horses. Cytogenet. Genome Res., 102, (2003), 207-210

LINDGREN, G.; SANDBERG, K.; PERSSON, H.; MARKLUND, S.; BREEN, M.; SANDGREN, B.; CARLSTEN, J.; ELLEGREN, H.:

A primary male autosomal linkage map of the horse genome. Genome Res., 8, (1998), 951-966

LINDGREN, G.; BREEN, M.; GODARD, S.; BOWLING, A.; MURRAY, J.; SCAVONE, M.; SKOW, L.; SANDBERG, K.; GUERIN, G.; BINNS, M.; ELLEGREN, H.:

Mapping of 13 horse genes by fluorescence in-situ hybridisation (FISH) and somatic cell analysis. Chrom. Res., 9, (2001), 53-59

LINDGREN, G.; SWINBURNE, J.E.; BREEN, M.; MARIAT, D.; SANDBERG, K.; GUERIN, G.; ELLEGREN, H.; BINNS, M.M.:

Physical anchorage and orientation of equine linkage groups by FISH mapping BAC clones containing microsatellite markers. Anim. Genet., 32, (2001), 37-39

LOCKE, M.M.; RUTH, L.S.; MILLON, L.V.; PENEDO, M.C.; MURRAY, J.D.; BOWLING, A.T.:

The cream dilution gene, responsible for the palomino and buckskin coat colours, maps to horse chromosome 21. Anim. Genet., 32, (2001), 340-343

LOCKE, M.M.; PENEDO, M.C.; BRICKER, S.J.; MILLON, L.V.; MURRAY, J.D.:

Linkage of the grey coat colour locus to microsatellites on horse chromosome 25. Anim. Genet., 33, (2002), 329-337

MARIAT, D. ; TAOURIT, S. ; GUERIN, G.:

A mutation in the MATP gene causes the cream coat colour in the horse. Genet. Sel. Evol., 35, (2003), 119-135

MARKLUND, S.; MOLLER, M.; SANDBERG, K.; ANDERSSON, L.:

A missense mutation in the gene for melanocyte-stimulating hormone receptor (MC1R) is associated with the chestnut coat color in horses. Mamm. Genome, 7 (1996), 895-899

MARKLUND, S.; MOLLER, M.; SANDBERG, K.; ANDERSSON, L.:

Close association between sequence polymorphism in the KIT gene and the roan coat colour in horses. Mamm. Genome, 10, (1999), 283-288

MAU, C.; PONCET, P.A.; BUCHER, B.; STRANZINGER, G.; RIEDER, S.:

Genetic mapping of dominant white (W), a homozygous lethal condition in the horse (Equus caballus). J. Anim. Breed. Genet., 121, (2004), 374-383

METALLINOS, D.L.; BOWLING, A.T.; RINE, J.:

A missense-mutation in the endothelin-B receptor gene is associated with Lethal White Foal Syndrome: an equine version of Hirschsprung disease. Mamm. Genome 9, (1998), 426-431

MILENKOVIC, D.; OUSTRY-VAIMAN, A.; LEAR, T.L.; BILLAULT, A.; MARIAT, D.; PIUMI, F.;

SCHIBLER, L.; CRIBIU, E.; GUERIN, G.:

Cytogenetic localization of 136 genes in the horse: Comparative mapping with the human genome. Mamm. Genome 13, (2002), 524-34

MILENKOVIC, D.; CHAFFAUX, F.; TAOURIT, S.; GUERIN, G.:

A mutation in the LAMC2 gene causes the Herlitz junctional epidermolysis bullosa (H-JEB) in two French draft horse breeds. Genet. Sel. Evol. 35, (2003), 249-256

MOMOZAWA, Y.; TAKEUCHI, Y.; KUSUNOSE, R.; KIKUSUI, T.; MORI, Y.:

Association between equine temperament and polymorphisms in dopamine D4 receptor gene. Mamm. Genome 16, (2005), 538-544

MOMOZAWA, Y.; TAKEUCHI, Y.; TOZAKI, T.; KIKUSUI, T.; HASEGAWA, T.; RAUDSEPP, T.; CHOWDHARY, B.; KUSUNOSE, R.; MORI, Y.:

Polymorphism identification, RH mapping and association analysis with the anxiety trait of the equine serotonin transporter (SLC6A4) gene. J. Vet. Med. Sci., 68, (2006), 619-621

MÜLLER, D.; KUIPER, H.; BÖNEKER, C.; MÖMKE, S.; DRÖGEMÜLLER, C.; CHOWDHARY, B.P.; DISTL, O.:

Assignment of BGLAP, BMP2, CHST4, SLC1A3, SLC4A1, SLC9A5, SLC20A1 to equine chromosomes by FISH and confirmation by RH mapping. Anim. Genet., 36, (2005), 457-461 
MUSILOVA, P.; KUBICKOVA, S.; VYCHODILOVA-KRENKOVA, L.; KRALIK, P.; MATIASOVIC, J.; HUBERTOVA, D.; RUBES, J.; HORIN, P.:

Cytogenetic mapping of immunity-related genes in the domestic horse. Anim. Genet., 36, (2005), 507510

MYKA, J.L.; LEAR, T.L.; HOUCK, M.L.; RYDER, O.A.; BAILEY, E.:

FISH analysis comparing genome organization in the domestic horse (Equus caballus) to that of the Mongolian wild horse (E. przewalski). Cytogenet. Genome Res., 102, (2003), 222-225

NERGADZE, S.G.; MAGNANI, E.; ATTOLINI, C.; BERTONI, L.; ADELSON, D.L.; CAPPELLI, K.; VERINI

SUPPLIZI, A.; GIULOTTO, E.:

Assignment of the equus caballus interleukin 8 gene (IL8) to chromosome 13q14.2 $\rightarrow 14.3$ by in situ hybridization. Cytogenet. Genome Res., 112, (2006), 341B

OAKENFULL, E.A.; BUCKLE, V.J.; CLEGG, J.G.:

Localization of the horse (Equus caballus) alpha-globin gene complex to chromosome 13 by fluorescence in situ hybridization. Cytogenet. Cell Genet., 62, (1993), 136-138

O’BRIEN, S.J.; GRAVES, M.J.A.:

Report of the committee on comparative gene mapping. Cytogenet. Cell Genet., 58, (1991), 1124-1151

PENEDO, M.C.T.; MILLON, L.V.; BERNOCO, D.; BAILEY, E.; BINNS, M.; CHOLEWINSKI, G.; ELLIS,

N.; FLYNN, J.; GRALAK, B.; GUTHRIE, A.; HASEGAWA, T.; LINDGREN, G.; LYONS, L.A.; ROED,

K.H.; SWINBURNE, J.E.; TOZAKI, T.:

International equine gene mapping workshop report: a comprehensive linkage map constructed with data from new markers and by merging four mapping resources. Cytogenet. Genome Res., 111, (2005), 5-15

PERROCHEAU, M.; BOUTREUX, V.; CHADI-TAOURIT, S.; CHOWDHARY, B.P.; CRIBIU, E.P.; DE JONG, P.J.; DURKIN, K.; HASEGAWA, T.; HIROTA, K.; IANUZZI, L.; INCARNATO, D.; LEAR, T.L.; RAUDSEPP, T.; PERUCATTI, A.; DI MEO, G.P.; ZHU, B.; GUERIN, G.:

Cytogenetic mapping of 150 genes on the horse genome. Plant and Animal Genome XIII Conference, (2005), Januar 15-19, 2005, San Diego, CA

PERROCHEAU, M.; BOUTREUX, V.; CHADI, S.; MATA, X.; DECAUNES, P.; RAUDSEPP, T.; DURKIN,

K.; INCARNATO, D.; IANNUZZI, L.; LEAR, T.L.; HIROTA, K.; HASEGAWA, T.; ZHU, B.; DE JONG, P.;

CRIBIU, E.P.; CHOWDHARY, B.P.; GUERIN, G.:

Construction of a medium-density horse gene map. Anim. Genet., 37, (2006), 145-155

PERRYMAN, L.E.:

Molecular pathology of severe combined immunodeficiency in mice, horses and dogs. Vet. Pathol., 41, (2004), 95-100

PIELBERG, G.; MIKKO, S.; SANDBERG, A.; ANDERSSON, L.:

Comparative linkage mapping of the Grey coat colour gene in horses. Anim. Genet., 36, (2005), 390395

POWER, M.M.:

XY sex reversal in a mare. Equine vet. J., 18, (1986), 233-236

RANEY, N.R.; GRAVES, K.T.; COTHRAN, E.G.; BAILEY, E.; COOGLE, L.:

Synteny mapping of the horse using a heterohybridoma panel. PAG VI Conference, Januar 18-22, (1998), San Diego, CA.

RAUDSEPP, T.; FRÖNICKE, L.; SCHERTHAN, H.; GUSTAVSSON, I.; CHOWDHARY, B.P.: Zoo-FISH delineates conserved chromosomal segments in horse and man. Chrom. Res., 4, (1996), 218225

RAUDSEPP, T.; OTTE, K.; ROZELL, B.; CHOWDHARY, B.P.:

FISH mapping of the IGF 2 gene in horse and donkey- detection of homology with HSA11. Mamm. Genome, 8 (1997), 569-572

RAUDSEPP, T.; KIJAS, J.; GODARD, S.; GUERIN, G.; ANDERSSON, L.; CHOWDHARY, B.P.:

Comparison of horse chromosome 3 with donkey and human chromosomes by cross-species painting and heterologous FISH mapping. Mamm. Genome, 10, (1999), 277-282

RAUDSEPP, T.; CHOWDHARY, B.P.:

Correspondence of human chromosomes 9, 12, 15, 16, 19 and 20 with donkey chromosomes refines homology between horse and donkey karyotypes. Chrom. Res., 9, (2001), 623-629

RAUDSEPP, T.; MARIAT, D.; GUERIN, G.; CHOWDHARY, B.P.:

Comparative FISH mapping of 32 loci reveals new homologous regions between donkey and horse karyotypes. Cytogenet. Genome Res., 94, (2001), 180-185

RAUDSEPP, T.; LEAR, T.L.; CHOWDHARY, B.P.:

Comparative mapping in equids: the asine $\mathrm{X}$ chromosome is rearranged compared to horse and Hartmann`s mountain zebra. Cytogenet. Genome Res., 96, (2002), 206-209

RAUDSEPP, T.; KATA, S.R.; PIUMI, F.; SWINBURNE, J.; WOMACK, J.E.; SKOW, L.E.; CHOWDHARY, B.P.: 
Conservation of gene order between horse and human X chromosomes as evidenced through radiation hybrid mapping. Genomics, 79, (2002), 451-457

RAUDSEPP, T.; SANTANI, A.; WALLNER, B.; KATA, S.R.; REN, C.; ZHANG, H.B.;WOMACK, J.E.; SKOW, L.C.; CHOWDHARY, B.P.:

A detailed physical map of the horse Y chromosome. Proc. Natl. Acad. Sci. USA, 101, (2004), 93219326

RIEDER, S.; TAOURIT, S.; MARIAT, D.; LANGLOIS, B.; GUERIN, G.: Mutations in the Agouti (ASIP), the extension (MC1R), and the brown (TRYP1) loci and their association to coat color phenotypes in horses (Equus caballus). Mamm. Genome, 12, (2001), 450-455

RIJKENHUIZEN, A.B.:

The arterial supply of the navicular bone in adult horses with navicular disease. Equine vet. J., 6, (1989), 413-417

RUDOLPH, J.A.; SPIER, S.J.; BYRNS, G.; ROJAS, C.V.; BERNOCO, D.; HOFFMAN, E.P.: Periodic paralysis in Quarter horses: a sodium channel mutation disseminated by selective breeding. Nat. Genet., 2, (1992), 144-147

SCHAMBONY, A.; GENTZEL, M.; WOLFES, H.; RAIDA, M.; NEUMANN, U.; TÖPFER-PETERSEN, E.: Equine CRISP-3: primary structure and expression in the male genital tract. Biochim. Biophys. Acta, 1387, (1998), 206-216

SHIN, E.K.; PERRYMAN, L.E.; MEEK, K.:

Evaluation of a test for identification of Arabian horses heterozygous for the severe combined immunodeficiency trait. J. Am. Med. Assoc., 211, (1997), 1268-1270

SHIUE, Y.L.; BICKEL, L.A.; CAETANO, A.R.; MILLON, L.V.; CLARK, R.S.; EGGLESTON, M.L.; MICHELMORE, R.; BAILEY, E.; GUERIN, G.; GODARD, S.; MICKELSON, J.R.; VALBERG, S.J.; MURRAY, J.D.; BOWLING, A.T.:

A synteny map of the horse genome comprised of 240 microsatellite and RAPD markers. Anim. Genet., 30, (1999), 1-9

SPIRITO, F.; CHARLESWORTH, A.; LINDER, K.; ORTONNE, J.P.; BAIRD, J.; MENEGUZZI, G.: Animal models for skin blistering conditions: absence of laminin 5 causes hereditary junctional mechanobullous disease in the Belgian horse. J. Invest. Dermatol., 119, (2002), 684-691

STRACHAN, T.; READ, A.P.: Molekulare Humangenetik. Spektrum Akademischer Verlag Heidelberg, (1996)

SVALASTOGA, E.; SMITH, M.:

Navicular disease in the horse. The subchondral bone pressure. Nordisk veterinaermedicine, 35, (1983), 31-37

SWINBURNE, J.; GERSTENBERG, C.; BREEN, M.; ALDRIDGE, V.; LOCKHART, L.; MARTI, E.; ANTCZAK, D.; EGGLESTON-STOTT, M.; BAILEY, E.; MICKELSON, J.; ROED, K.; LINDGREN, G.; VON HAERINGEN, W.; GUERIN, G.; BJARNASON, J.; ALLEN, T.; BINNS, M.:

First comprehensive low-density horse linkage map based on two 3-generation, full-sibling, cross-bred horse reference families. Genomics, 66, (2000), 123-134

SWINBURNE, J.E.; HOPKINS, A.; BINNS, M.M.:

Assignment of the horse grey coat colour gene to ECA 25 using whole genome scanning. Anim. Genet., 33, (2002), 338-342

SWINBURNE, J.E.; TURNER, A.; ALEXANDER, L.J.; MICKELSON, J.R.; BINNS, M.M.: Characterization and linkage map assignments for 61 new horse microsatellite loci (AHT49-109). Anim. Genet., 34, (2003), 65-68

SWINBURNE, J.E.; BOURSNELL, M.; HILL, G.; PETTITT, L.; ALLEN, T.; CHOWDHARY, B.P.; HASEGAWA, T.; KUROSAWA, M.; LEEB, T.; MASHIMA, S.; MICKELSON, J.R.; RAUDSEPP, T.; TOZAKI, T.; BINNS, M.:

Single linkage group per chromosome genetic linkage map for the horse, based on two three-generation, full-sibling, crossbred horse reference families. Genomics, 87, (2006), 1-29

TALLMADGE, R.L.; LEAR, T.L.; JOHNSON, A.K.; GUERIN, G.; MILLON, L.V.; CARPENTER, S.L.; ANTCZAK, D.F.: Characterisation of the ß2-microglobulin-gene of the horse. Immunogenet., 54, (2003), 725-733

TERRY, R.R.; BAILEY, E.; BERNOCO, D.; COTHRAN, E.G.: Linked markers exclude KIT as the gene responsible for appaloosa coat colour spotting patterns in horses. Anim. Genet., 32, (2001), 98-101

TERRY, R.B.; BAILEY, E.; LEAR, T.; COTHRAN, E.G.: Rejection of MITF and MGF as the genes responsible for appaloosa coat colour patterns in horses. Anim. Genet., 33, (2002), 82-84

TERRY, R.B.; ARCHER, S.; BROOKS, S.; BERNOCO, D.; BAILEY, E.: Assignment of the appaloosa coat colour gene (LP) to equine chromosome 1. Anim. Genet., 35, (2004), 134-137 
TOZAKI, T.; PENEDO, M.C.; OLIVEIRA, R.P.; KATZ, J.P.; MILLON, L.V.; WARD, T.; PETTIGREW, D.C.; BRAULT, L.S.; TOMITA, M.; KUROSAWA, M.; HASEGAWA, T.; HIROTA, K.: Isolation, characterization and chromosome assignment of 341 newly isolated equine TKY microsatellite markers. Anim. Genet., 35, (2004), 487-496

VALBERG, S.J.; WARD, T.L.; RUSH, B.; KINDE, H.; HIRARAGI, H.; NAHEY, D.; FYFE, J.; MICKELSON, J.R.:

Glycogen branching enzyme deficiency in quarter horse foals. J. Vet. Intern. Vet., 15, (2001), 572-580

VAN DE LEST, C.H.A.; VAN DEN HOOGEN, B.M.; VAN WEEREN, P.R.; BROUWERS, J.F.H.M.; VAN GOLDE, L.M.G.; BARNEVELD, A.:

Changes in bone morphogenic enzymes and lipid composition of equine osteochondrotic subchondral bone. Equine vet. J., Suppl. 31, (1999), 31-37

WAGNER, M.L.; RAUDSEPP, T.; GOH, G.; AGARWALA, R.; SCHÄFFER, A.A.; DRANCHAK, P.K.; BRINKMEYER-LANGFORD, C.; SKOW, L.C.; CHOWDHARY, B.P.; MICKELSON, J.R.: A 1.3-Mb interval map of equine homologs of HSA2. Cytogenet. Genome Res. 112, (2006), 227-234

WARD, T.L.; VALBERG, S.J.; LEAR, T.L.; GUERIN, G.; MILENKOVIC, D.; SWINBURNE, J.E.; BINNS, M.M.; RAUDSEPP, T.; SKOW, L.; CHOWDHARY, B.P.; MICKELSON, J.R.:

Genetic mapping of GBE1 and its association with glycogen storage disease IV in American Quarter horses. Cytogenet. Genome Res. 102, (2003), 201-206

WARD, T.L.; VALBERG, S.J.; ADELSON, D.L.; ABBEY, C.A.; BINNS, M.M.; MICKELSON, J.R.: Glycogen branching enzyme (GBE1) mutation causing equine glycogen storage disease IV. Mamm. Genome 15, (2004), 570-577

WILLIAMS, H.; RICHARDS, C.M.; KONFORTOV, B.A.; MILLER, J.R.; TUCKER, E.M.: Synteny mapping in the horse using horse-mouse heterohybridomas. Anim. Genet. 24, (1993), 257-260

WITTWER, C.; DISTL, O.:

Mapping quantitative trait loci for osteochondrosis in South German Coldblood horses. Proceedings of the $30^{\text {th }}$ International Conference on Animal Genetics, ISAG 2006, 20-25 August 2006, Porto Seguro, Brazil, D330

WITTWER, C.; LÖHRING, K.; HAMANN, H.; ROSENBERGER, E.; DISTL, O.:

Mapping of quantitative trait loci for osteochondrosis in South German Coldblood horses. Anim. Genet., (2006), in review

YANG, G.C.; CROAKER, D.; ZHANG, A.L.; MANGLICK, P.; CARTMILL, T.; CASS D.:

A dinucleotide mutation in the endothelin-B receptor gene is associated with lethal white foal syndrome (LWFS): a horse variant of Hirschsprung disease (HSCR). Hum. Mol. Genet., 7, (1998), 1047-1052

YANG, F.; FU, B.; O`BRIEN, P.C.; NIE, W.; RYDER, O.A.; FERGUSON-SMITH, M.A.:

Refined genome-wide comparative map of the domestic horse, donkey and human based on crossspecies chromosome painting: insight into the occasional fertility of mules. Chromosome Res., 12, (2004), 65-76

ZEILMANN, M.:

HYPP - hypercalemic periodic paralysis in horses. Tierärztl. Prax., 21, (1993), 524-527

Received: 2006-09-11

Accepted: 2006-10-20

\author{
Authors' address \\ DOROTHEE STÜBS, Prof. Dr. OTTMAR DISTL* \\ Institute for Animal Breeding and Genetics \\ University of Veterinary Medicine Hannover \\ Bünteweg 17p \\ 30559 HANNOVER \\ GERMANY \\ *Corresponding Author \\ E-Mail: ottmar.distl@tiho-hannover.de
}

